\title{
Combining Pyramidal Tract Mapping, Microscopic-Based Neuronavigation, and Intraoperative Magnetic Resonance Imaging Improves Outcome of Epilepsy Foci Resection in the Sensorimotor Cortex
}

\author{
Piramidal Traktus Haritalama, Mikroskopi Tabanl Nöronavigasyon \\ ve Intraoperatif Manyetik Rezonans Görüntülemenin Birleştirilmesi \\ Sensorimotor Korteksteki Epilepsi Odakları Rezeksiyonunun Sonuçlarını \\ İyileştirir
}

Zhi-Qiang CUI ${ }^{1}$, Zhi-Pei LING ${ }^{1}$, Hui-Fang SONG ${ }^{2}$, Shen HU ${ }^{1}$, Guo-Chen SUN ${ }^{1}$, Xiao-Lei CHEN ${ }^{1}$, Long-Sheng PAN ${ }^{1}$, Chong $\mathrm{LI}^{1}$, Bai-Nan XU ${ }^{1}$

${ }^{1}$ Chinese PLA General Hospital, Chinese PLA Postgraduate Medical School, Department of Neurosurgery, Beijing, China

${ }^{2}$ Hebei Province Luan County People's Hospital, Department of Neurology, Hebei Province, China

Corresponding Author: Xu BAINAN / E-mail: bnx301hos@163.com

\section{ABSTRACT}

AIM: To explore the clinical value of combining pyramidal tract mapping, microscopic-based neuronavigation, and intraoperative magnetic resonance imaging (iMRI) in the surgical treatment of epileptic foci involving sensorimotor cortex.

MATERIAL and METHODS: We retrospectively analyzed 69 patients with focal epilepsy involving motor and sensory cortex. The surgical operations in Group I ( $n=38$ ) were performed under the guidance of conventional neuronavigation, and the operations of Group II ( $n=31$ ) were aided by combining pyramidal tract mapping, microscopic-based neuronavigation and the iMRI technique. Chi square test was used to compare seizure outcome and neurological deficits across groups.

RESULTS: 7 patients (18.4\%) in Group I, and 3 patients (9.7\%) in Group II didn't recover to the level of preoperative strength within one year post-operation. The 2-year follow-up survey showed that more patients in Group II compared to Group I $(71 \%$ vs. $55.3 \%, p=0.181)$ had a good outcome (Engel class I II).

CONCLUSION: The techniques of combining pyramidal tract mapping, microscopic-based neuronavigation and iMRI aid in precise mapping and hence resection of epileptic foci in sensorimotor cortex, which lead to improvement of surgical efficacy and significant reduction of postoperative loss of function.

KEYWORDS: Intraoperative magnetic resonance imaging (iMRI), Microscopic-based neuronavigation, Pyramidal tract mapping, Epilepsy in the sensorimotor cortex

öz

AMAÇ: Sensorimotor korteksle ilgili epileptik odakların cerrahi tedavisinde piramidal traktus haritalama, mikroskopi tabanlı nöronavigasyon ve intraoperatif manyetik rezonans görüntülemenin (iMRG) birleştirilmesinin klinik değerini incelemek.

YÖNTEM ve GEREÇLER: Motor ve duyusal korteksle ilgili fokal epilepsili 69 hastayı retrospektif olarak inceledik. Grup l'deki ( $\mathrm{n}=38$ ) cerrahi operasyonlar, geleneksel nöronavigasyon ile yapılırken, Grup II $(n=31)$ operasyonları piramidal traktus haritalama, mikroskopi tabanlı nöronavigasyon ve iMRG tekniği birleştirilerek yapıldı. Gruplar arasında epileptik nöbet açısından sonucu ve nörolojik defisitleri karşılaştırmak için Ki kare testi kullanıldı.

BULGULAR: Grup I'de 7 hasta $(\% 18,4)$ ve Grup II'de 3 hasta $(\% 9,7)$ operasyon sonrası bir yıl içinde preoperatif güç düzeyine ulaşamadı. 2 yıllık izlem anketi Grup I ile karşılaştırıldığında Grup II'de daha fazla hastanın iyi bir sonuç (Engel seviye I - II) elde ettiğini gösterdi.

SONUÇ: Piramidal traktus haritalama, mikroskopi tabanlı nöronavigasyon ve iMRG hassas haritalamaya ve böylece sensorimotor kortekste epileptik odakların rezeksiyonuna, sonuçta da cerrahi etkinliğin artmasına ve postoperatif işlevsel kayıpta önemli azalmaya yardımcıdır.

ANAHTAR SÖZCÜKLER: İntraoperatif manyetik rezonans görüntüleme (iMRG), Mikroskopi bazlı nöronavigasyon, Piramidal traktus haritalama, Sensorimotor kortekste epilepsi 


\section{INTRODUCTION}

Surgical treatment of epileptic foci in the sensorimotor cortex is particularly challenging, because these cortical areas are critical for movement and sensory function and their resection may result in unacceptable neurological deficits. Recent advances in neuroimaging techniques have improved the mapping of epileptic foci and lesions in patients with neocortical epilepsy, making more precise resections possible. Functional MRI (fMRI) and diffusion tensor tractography (DTT) are amongst the non-invasive neuroimaging methods. One can locate the eloquent cortex with the former, and track the white matter fibers with the latter (5). With FMRI and DTI, the location of lesions can be visualized relative to the adjacent eloquent cortex and fiber tracts, which allows a surgeon to preoperatively design optimal resection trajectories for maximally removing the lesions as well as preserving function. Beyond preoperative mapping and planning, the intraoperative MRI (iMRI) technique further provides immediate evaluation of the surgical outcome (2). To make full use of the neuroimaging data, microscope-based functional neuronavigation allows on-line evaluation of the extent of resection by continuously updated intraoperative images with brain shift addressed, which makes intraoperative adaptation of the surgery procedure feasible.

Here we describe the neurological deficits and seizure outcomes of operations on 69 patients. The patients went through surgical treatment for intractable epilepsy involving the sensorimotor cortex. Operations for 38 patients were performed under the guidance of conventional neuronavigation between January 2006 and December 2008, and operations for 31 patients were guided by combining pyramidal tract mapping, microscopic-based neuronavigation and the iMRI technique between January 2009 and December 2010. In this paper, we focus on comparisons of seizure and functional outcomes between the two patient groups who underwent different surgical procedures.

\section{MATERIAL and METHODS}

\section{Patients}

69 patients with drug-resistant epilepsy involving the sensorimotor cortex were treated with surgical resection in General Hospital of PLA between January 2006 and December 2010. The subjects were 37 males and 32 females. The types of seizure of the subjects included simple partial seizures, complex partial seizures, generalized tonic-clonic seizures, and status epilepticus. Common pre-surgical evaluation procedure was applied to all patients, including continuous video electroencephalography (EEG) monitoring and magnetic resonance imaging (MRI). Additional examinations including magnetoencephalography (MEG), positron emission tomography (PET), and intracranial grids were performed for a few patients. All the patients were divided into two groups chronologically, who underwent different surgical procedures: Group I $(n=38)$ were surgically treated with the guidance of conventional neuronavigation between January 2006 and December 2008, and Group II $(n=31)$ were surgically treated with the guidance of pyramidal tract mapping, microscopic-based neuronavigation, and the iMRI technique between January 2009 and December 2010. The clinical characteristics in Group I and II are summarized in Table I.

\section{Image Acquisition}

MRI was performed for all the patients using 1.5T scanners (Siemens Espree, Erlangen, Germany). For Group II, to get the diffusion tensor imaging, we applied a single-shot spin-echo diffusion-weighted echo planar imaging sequence (echo time, 147 milliseconds; repetition time, 9400 milliseconds; matrix size, $128 \times 128$; field of view, $251 \times 251 \mathrm{~mm}$; slice th ickness, $3 \mathrm{~mm}$; bandwidth, $1502 \mathrm{~Hz}$ per pixel; diffusion-encoding gradients in 12 directions using b values of 0 and $1000 \mathrm{~s} / \mathrm{mm}^{2}$; and voxel size, $1.9 \mathrm{~mm} \times 1.9 \mathrm{~mm} \times 3 \mathrm{~mm}$ ). We used 40 slices, no intersection gap, 40 continuous free interval collection slices, and 5 time repetitions. To image the eloquent cortex, we used a block design composed of stimulation and rest. The hand and foot movement tasks were used to map functional areas specialized in hand and foot movements.

For fiber tracking, we used the "fiber tracking" module to reconstruct the corticospinal pathway and the sensory pathway. We used a multi-volume of interest (VOI) algorithm for fiber tracking, and the tract seeding was performed by defining a rectangular VOI in the co-registered standard T1 anatomical datasets. To reconstruct the corticospinal tract,

Table I: Clinical Characteristics in Patient Group I and II

\begin{tabular}{|l|c|c|c|c|}
\hline Characteristic & Group I & Group II & Total & p-value \\
\hline No. of patients & 38 & 31 & $69(100)$ & \\
\hline Mean age (yr) & $19.7 \pm 10.48$ & $20.1 \pm 10.1$ & $19.9 \pm 10.2$ & $0.850^{\mathrm{a}}$ \\
\hline Mean duration of epilepsy (yr) & $9.6 \pm 6.5$ & $12.4 \pm 9.9$ & $10.9 \pm 8.3$ & $0.179^{\mathrm{a}}$ \\
\hline Identifiable lesions on MRI & $35(92.1)$ & $24(83.9)$ & $59(85.5)$ & $0.168^{\mathrm{b}}$ \\
\hline Magnetoencephalography & $21(55.3)$ & $13(41.9)$ & $43(62.3)$ & $0.271^{\mathrm{b}}$ \\
\hline Positron emission tomography & $13(34.2)$ & $7(22.6)$ & $20(29.0)$ & $0.290^{\mathrm{b}}$ \\
\hline Intracranial grids & $36(94.7)$ & $26(83.9)$ & $62(89.9)$ & $0.230^{\mathrm{c}}$ \\
\hline
\end{tabular}

Values are presented as mean $\pm S D$ or number (\%). a: T-test, $\boldsymbol{b}:$ Chi-square test, c: Fisher's Exact Test. 
the first region of interest (ROI) was placed on the subcortical white matter in the precentral gyrus, and the second ROI was placed on the cerebral peduncle. To reconstruct the sensory tract, the first ROI was placed on the subcortical white matter in the post-central gyrus, and the second ROI was placed on the cerebral peduncle. After selecting the appropriate fiber bundle, a three-dimensional (3D) object was created automatically by wrapping the neighboring fibers with a hull.

For segmentation and $3 \mathrm{D}$ reconstruction of the lesion, we used the "object creation" module. Segmentation of the lesion was performed on the $\mathrm{T} 2$ fluid attenuated inversion recovery (FLAIR) anatomical data set, on a slice-by-slice basis. After all slices containing the lesion were outlined, a 3D image of the lesion was reconstructed and its volume was automatically calculated (Figure1A-C).

\section{Microscope-Based Neuronavigation and Intraoperative Magnetic Resonance Imaging}

The DTI and FMRI data were co-registered with anatomical images in Group II. The technical details have been published elsewhere $(10,21,22)$. The contours of lesions, pyramidal tract, and motor cortex were displayed in the viewing field of the neuronavigation microscope (Pentero, Carl Zeiss, Oberkochen, Germany). We locked the epileptic foci by the contacts of electrodes, and then removed the intracranial grids. The projection of the epileptic foci was automatically visualized (Figure 2A,B; 3A,B).

For each patients in Group II, iMRI was performed to examine whether the corticospinal tract was damaged and whether the lesion was completely resected, so as to make the decision if we should continue the resection (Figure 4A-D). In the cases when further resection was needed, the neuronavigation was updated based on the intraoperative MRI images. Mapping of the eloquent fiber bundles was also updated with the fiber tracking module.

\section{Evaluation of Seizure Outcome and Neurological Deficits}

All patients were followed for at least 2 years and the seizure outcome was compared at 2-year follow-up. The seizure outcome was evaluated according to Engel's classification (9). Class I patients were those who showed absence of seizures or presence of auras only or presence of seizures only during drug withdrawal, Class II patients had rare seizures or nocturnal seizures only, Class III patients showed worthwhile improvement, and Class IV patients showed no improvement. The neurological deficits were evaluated at one week and one year post-operation. Chi square test was used to compare the seizure outcome and neurological deficits across patient groups.

\section{RESULTS}

\section{Complications and Seizure Outcomes}

The result of complication and seizure outcomes for the two groups of patients are summarized in Table II. 18 patients (50\%) in Group I developed at least one new severe postoperative neurological deficit in one week after the operation, whereas only eight patients (25.8\%) in Group II developed equivalent neurological deficit. 7 patients (18.4\%) in Group I and 3 patients (9.7\%) in Group II did not recover to the level of the preoperative strength within one year postoperation. Patients in Group II demonstrated significantly less hemiparesis in one week post-operation (Pearson's ChiSquare=4.106, $\mathrm{P}=0.043$ ). The 2-year follow-up survey showed
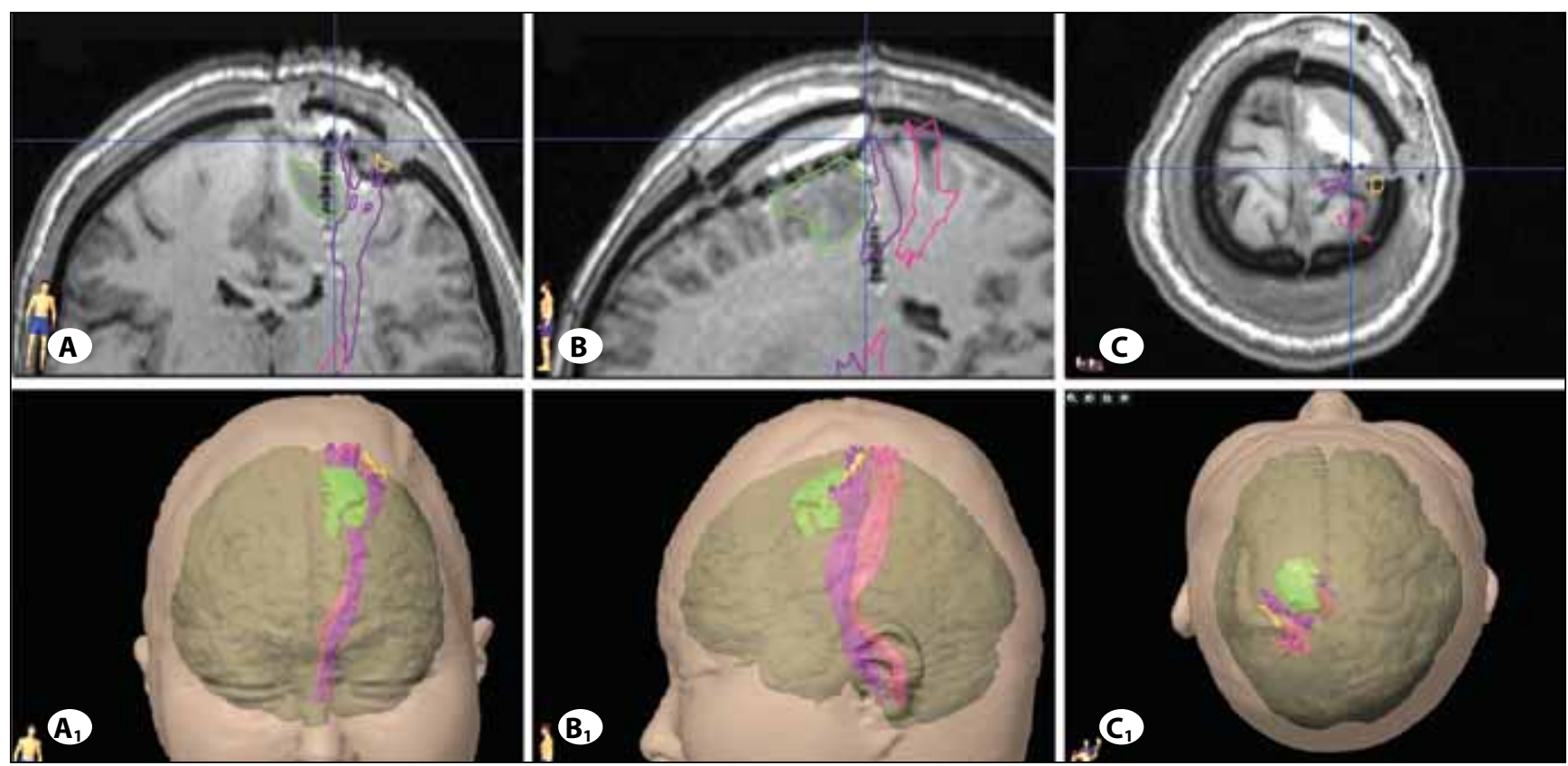

Figure 1: A-C) In the coronal, sagittal and axial T1 MRI and A1-C1) 3D views, the lesion (green), the pyramidal tract (pink), and motor cortex (yellow) were shown. 
Table II: Comparison of the Seizure Outcomes and Neurologic Deficits Between Group I and II

\begin{tabular}{|c|c|c|c|c|c|c|}
\hline \multirow{2}{*}{$\begin{array}{l}\text { Total Number } \\
(n=69)\end{array}$} & \multicolumn{2}{|c|}{ Engel Outcome } & & \multicolumn{2}{|c|}{ Neurologic Deficits (one week) } & \\
\hline & Class I II & Class III IV & & No Hemiparesis & Hemiparesis & \\
\hline$p$-value & & & $0.181^{\mathrm{a}}$ & & & $0.043^{a *}$ \\
\hline Group I $(n=38)$ & $21(55.3)$ & $17(44.7)$ & & $18(50.0)$ & $18(50.0)$ & \\
\hline Group II $(n=31)$ & $22(71.0)$ & $9(29.0)$ & & $23(74.2)$ & $8(25.8)$ & \\
\hline
\end{tabular}

Values are presented as number (\%). a: Chi-square test. ${ }^{*} p<0.05$.


Figure 2: A) The lesion (green) and the pyramidal tract (pink) were projected onto the scalp in the viewing field of the neuronavigation microscope. B) The epileptic focus was marked with " + ". The lesion (within green dotted contour), pyramidal tract (within pink dotted contour), motor cortex (within white dotted contour) and the epileptic focus (yellow + ) were clearly visualized in the viewing field of the neuronavigation microscope.
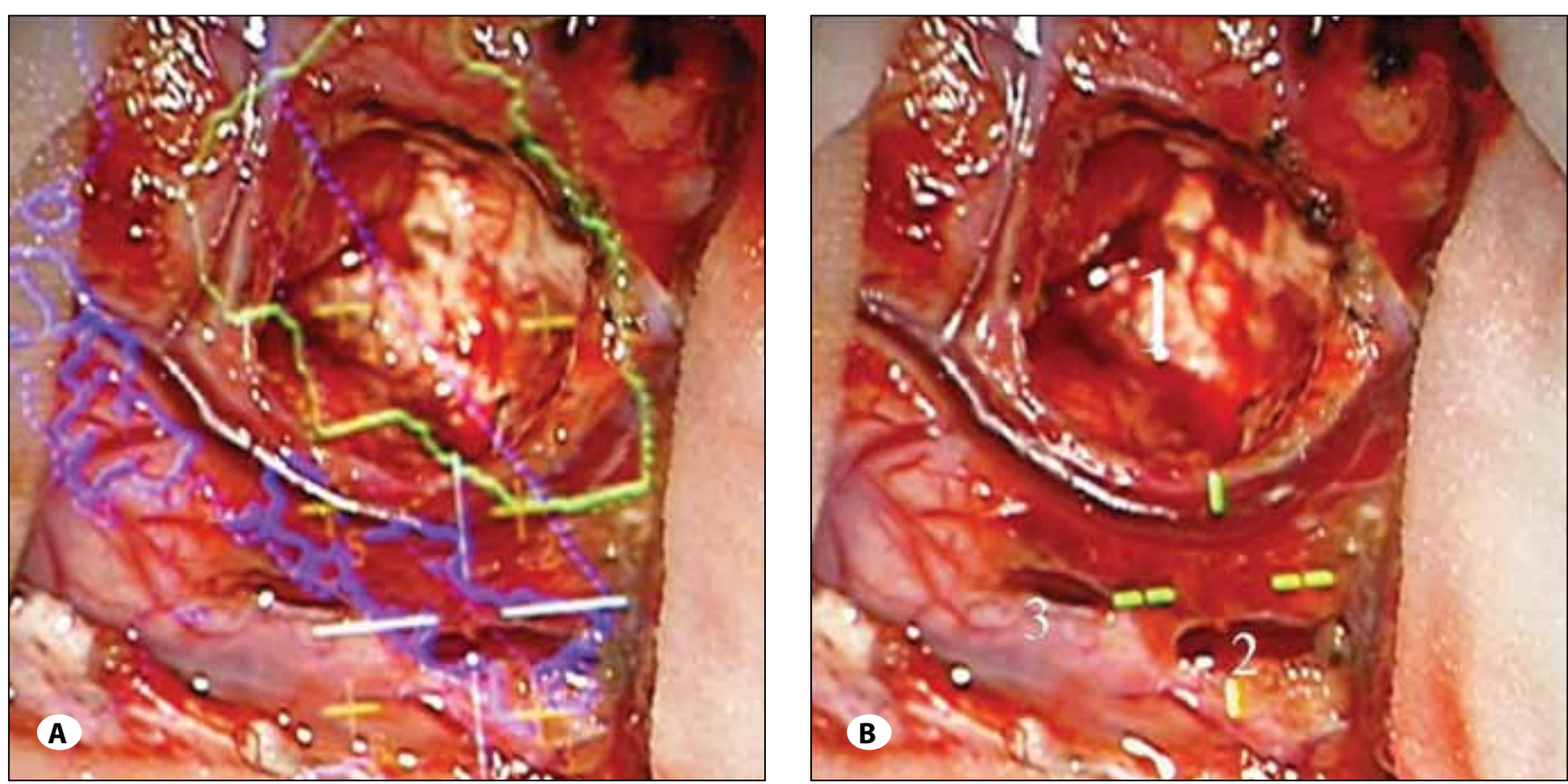

Figure 3: During the operation, the surgeon was reminded when the manipulation was close to the pyramidal tract and an intraoperative MRI was necessary, by turning the dotted contour into a solid contour. A) The lesion was completely removed while the pyramidal tract was kept intact. Although the epileptic foci $(+3,+6)$ were located in the precentral gyrus, they showed no functional relevance according to the intracranial electrode mapping, and were thus resected. B) Removing the projection, a big cavity (1) of the lesion and two small cavities $(2,3)$ of the epileptic foci were clearly shown. The cavities $(2,3)$ of the epileptic foci were small, because we only resected the epileptic foci under the pia mater while kept the pia mater minimally damaged and the sulcus vessels (especially vessels in the central sulcus) preserved. 
that $71 \%$ patients in Group II got a good outcome (Engel class I II), outperforming 55.3\% in Group I (Pearson's ChiSquare $=1.793, \mathrm{P}=0.181$ ).

\section{Times of iMRI scans}

The total amount of iMRI scans performed for Group II was 57. The iMRI was performed once for 11 patients, twice for 14 patients, and three times for 6 patients. For the 6 patients who underwent three $\mathrm{iMRI}$ scans, the seizure outcome is not ideal, but most of them (5 out of 6 patients) developed none-hemiparesis. Fewer times of iMRI (once and twice) were performed for the other 25 patients, most of whom achieved a good outcome in terms of epilepsy control, yet with a higher rate of hemiparesis. Although fewer times of iMRI (once and twice) is likely associated better seizure outcome and a higher rate of hemiparesis, the observation is not statistically significant. The relationship between seizure outcomes, postoperative deficits and times of iMRI scans in Group II is summarized in Table III.

\section{DISCUSSION}

Diffusion tensor imaging (DTI) has become one of the most popular MRI techniques in both scientific research and clinical applications $(17,14,30,19,20)$, which enables visualization

Table III: Seizure Outcomes and Postoperative Deficits in Relation to Times of iMRI Scans in Group II Patients

\begin{tabular}{|c|c|c|c|c|c|c|c|}
\hline \multirow{2}{*}{$\begin{array}{l}\text { Times of iMRI } \\
\text { Scans }\end{array}$} & \multirow{2}{*}{$\begin{array}{c}\text { Total } \\
\text { Number }\end{array}$} & \multicolumn{2}{|c|}{ Engel Outcome } & & \multicolumn{2}{|c|}{ Neurologic Deficits } & \\
\hline & & Class I II & Class III IV & & No Hemiparesis & Hemiparesis & \\
\hline p-value & & & & $0.966^{a}$ & & & $0.643^{a}$ \\
\hline Total number & 31 & $22(71.0)$ & $9(29.0)$ & & $23(74.2)$ & $8(25.8)$ & \\
\hline 1 time & 11 & $8(72.7)$ & $3(27.3)$ & & $7(63.6)$ & $4(36.4)$ & \\
\hline 2 times & 14 & $10(71.4)$ & $4(28.6)$ & & $11(78.6)$ & $3(21.4)$ & \\
\hline 3 times & 6 & $4(66.7)$ & $2(33.3)$ & & $5(83.3)$ & $1(16.7)$ & \\
\hline
\end{tabular}

Values are presented as number (\%). a: Kruskal-Wallis Test.
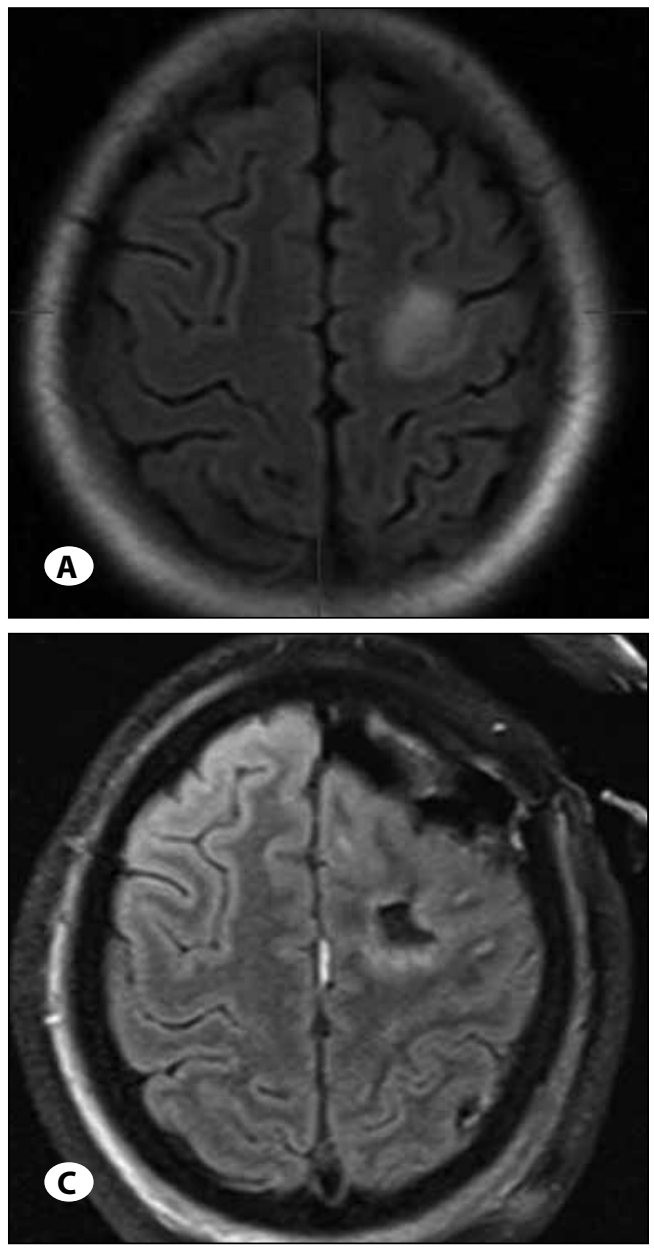
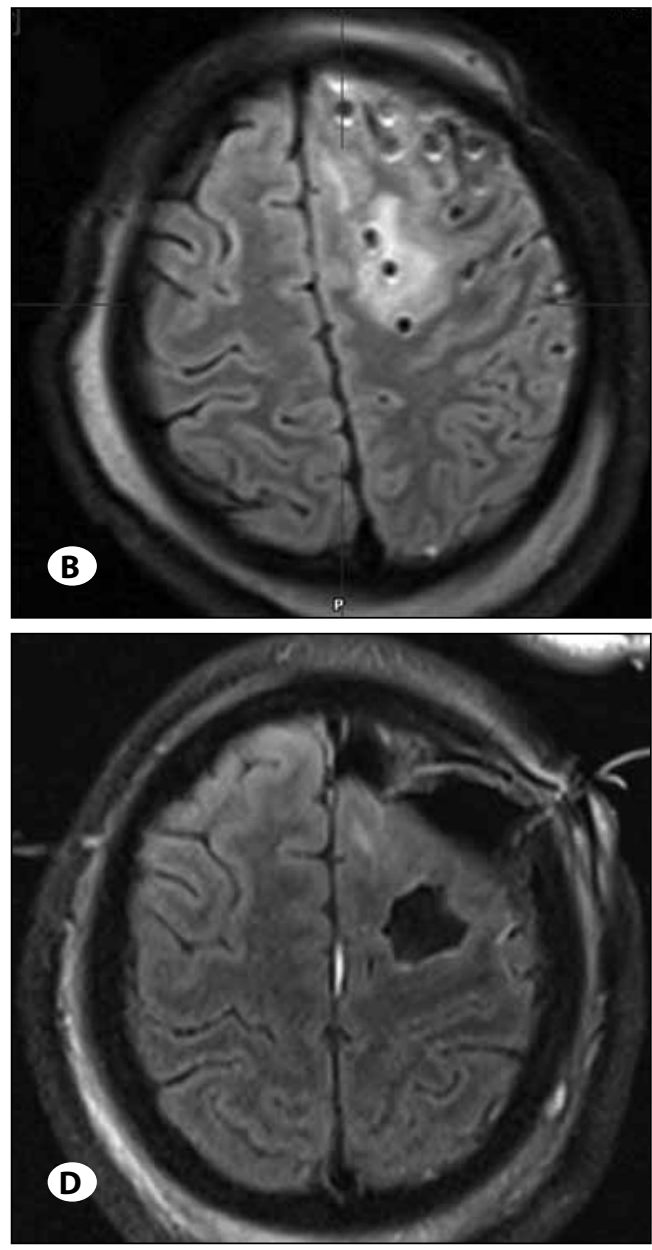

Figure 4: A) The axial FLAIR-weighted MRI showed a lesion in the left precentral gyrus. B) The axial FLAIR-weighted MRI showed the relationship between the lesion and the electrodes (depth electrodes and surface strip electrodes). C) The first iMRI (axial FLAIRweighted MRI) showed that the surrounding tissue of the lesion was not removed. D) The second iMRI (axial FLAIR-weighted MRI) showed a complete resection of the lesion. 
and characterization of white matter tracts in 3D (15). The integration of DTI and fMRI data with 3D anatomic images has been widely adopted for preoperative neurosurgical planning and intraoperative identification of eloquent structures, which is known as functional neuronavigation $(23,24)$. Recently the DTI technique has been also applied to evaluate the relationship between white matter fibers and the epileptic foci in the temporal lobe or in the occipital lobe epilepsy $(26,11,31,28,29)$, for better decision making on resection sizes and for better estimation of the potential functional deficits. However, there are few applications in epilepsy involving the sensorimotor cortex (32). In our cohort, the fiber bundles, including both the corticospinal tract and the sensory tract of Group II, were successfully tracked with DTI. The relative positions of the intracranial grids, lesion, epileptic foci, functional cortex and pyramidal tract were clearly visualized with $3 \mathrm{D}$ reconstruction, based on which we were able to design suitable trajectories for the resection of epileptic foci and lesions.

Intraoperative MRI has been proven to be a sound technique that allows a neurosurgeon to on-line update neuronavigation data, to evaluate the extent of tumor resection, to correct for brain shift, to modify surgery strategy if necessary, to guide instruments to the lesion, and to evaluate presence of intraoperative complications at the end of surgery (13). So far, the intraoperative MRI technique has been mostly applied in neurosurgical resection of tumors, rather than in epilepsy surgery. For the two available iMRI applications in epilepsy surgery, the epileptic foci were both located in the temporal lobe $(3,12)$. In this paper, we applied the iMRI technique, combined with microscopic-based neuronavigation to 31 patients in Group II. During the operations, we locked epileptic foci by the electrodes, so that even when the microscope was moved, the projection of epileptic foci would not shift. When a dotted contour representing a lesion or corticospinal tract was reached, it would turn to a solid contour in the field of view of the microscope. The change of contour would remind the surgeon pausing the resection and running another iMRI scan. If the iMRI scan showed existence of residual lesion that might be due to intraoperative brain shift, and its border did not reach the pyramidal tract, the resection would be resumed to remove the residual lesion. In the cases when the iMRI scan showed that the residual lesion extenuated into the pyramidal tract, no further resection was performed. Specifically, we found that the iMRI technique combined with microscope-based neuronavigation was quite useful for the resection of epileptic foci as cortical dysplasia and low-grade glioma, which were visible in MRI images but intractable in the microscope.

Half of the patients in Group I had postoperative neurological deficits during the acute stage, whereas did only eight patients (25.8\%) in Group II. Moreover, seven patients (18.4\%) in Group I and only three patients (9.7\%) in Group II has developed permanent postoperative deficits. It is noteworthy that the low occurrence of neurological deficits in Group II also outperforms previously reported $(16,18,4,8,6,25)$ data with conventional surgical treatment similar to Group I. For example, in Lehman et al's study (16) $40 \%$ of the patients developed transient deficits and 30\% developed permanent deficits; and Margarita (18) reported that 55 patients with epilepsy involved perirolandic area underwent a resection surgery with or without multiple subpial transections (MSTs), and $50 \%$ of patients developed permanent post-surgical deficits. Despite the variation in procedures of preoperative assessment, durations of follow-up survey, and individual difference of patients (e.g. etiology, complex pathology, extensive epileptogenicity, and severety of seizures), the major difference between treatments in Group II and Group I as well as previously reported data is that the former was guided by combining pyramidal tract mapping, microscopicbased neuronavigation and the iMRI technique, rather than conventional neuronavigation alone. Therefore, the lower occurrence of hemiparesis in Group II is likely due to the advanced neuroimaging and surgical techniques to visualize of the complex relationships between the lesion, epileptic foci, functional cortex, and pyramidal tract.

The reduction of postoperative neurological deficits in Group II does not come at the price of hampered seizure control. Compared to Group I patients (55.3\%, Engel I-II), the Group II patients (71\%) actually had a higher rate of seizure control at 2 year follow up, though not statistically significant. The seizure control we observed was comparable to previous studies. Behdad (1) reported 24 patients with epilepsy arising from the sensorimotor (rolandic) cortex, who underwent surgical management, Engel I-II outcome was achieved in $77 \%$ of patients. For other studies, Margarita (18) reported that Engel I-II outcome in 55 patients was 46\%, Devinsky et al. (8) reported 54\%, Otsubo et al. (25) reported 43\%, Pilcher et al. (27) reported $48.7 \%$, Cukiert et al. (7) reported $75 \%$, and CohenGadol et al. (6) reported $80 \%$ but with a small sample size ( $\mathrm{n}$ $<5$ ). Despite the variation in the rate of seizure control which might be explained by the individual difference of patients, we did observed that Group II achieved a better result than Group I, with the rate of seizure control (71\%) comparable to the highest rate reported elsewhere, which suggests the usefulness of the advanced intraoperative imaging. Some epileptic foci such as cortical dysplasia could not be visually distinguished from normal tissues even in a microscope. In that case, the iMRI technique helped us evaluate whether the resection of lesions was completed or further resections were necessary. Moreover, the intraoperative brain shift resulted from incomplete resection, lesion resection, cerebral edema, use of brain retractors, or cerebrospinal fluid (CSF) runoff could be well addressed by the iMRI technique.

Although current evidence suggested that less times of iMRI (once and twice) predict good seizure outcome and higher rate hemiparesis, more data remain to be collected to full characterize the relationship between seizure outcomes, postoperative deficits and times of iMRI

\section{CONCLUSION}

This procedure reported in this paper which combines pyramidal tract mapping, microscopic-based neuronavigation 
and the iMRI technique can guide the surgeons to precise resection of the lesions and epileptic foci located in sensorimotor cortex, which improves efficacy of the surgery, and significantly reduces the postoperative loss of function with no raises in seizure outcome.

\section{ACKNOWLEDGMENTS}

The authors thank Dr Rui Xu (Tsinghua University) for his professional editing and valuable suggestions.

\section{REFERENCES}

1. Behdad A, Limbrick DD Jr, Bertrand ME, Smyth MD: Epilepsy surgery in children with seizures arising from the rolandic cortex. Epilepsia 50:1450-1461, 2009

2. Black PM, Moriarty T, Alexander E 3rd, Stieg P, Woodard EJ, Gleason PL, Martin CH, Kikinis R, Schwartz RB, Jolesz FA: Development and implementation of intraoperative magnetic resonance imaging and its neurosurgical applications. Neurosurgery 41:831-845, 1997

3. Buchfelder M, Ganslandt O, Fahlbusch R, Nimsky C: Intraoperative magnetic resonance imaging in epilepsy surgery. J Magn Reson Imaging12:547-555, 2000

4. Cascino GD: Surgical treatment for extratemporal epilepsy. Curr Treat Options Neurol 6: 257-262, 2005

5. Clark CA, Barrick TR, Murphy MM, Bell BA: White matter fiber tracking in patients with space-occupying lesions of the brain: A new technique for neurosurgical planning? Neuroimage 20:1601-1608, 2003

6. Cohen-Gadol AA, Britton JW, Collignon FP, Bates LM, Cascino GD, Meyer FB: Nonlesional central lobule seizures: Use of awake cortical mapping and subdural grid monitoring for resection of seizure focus. J Neurosurg 98: 1255-1262, 2003

7. Cukiert A, Buratini JA, Machado E, Sousa A, Vieira J, Forster C, Argentoni M, Baldauf C, Frayman L: Seizure's outcome after cortical resections including the face and tongue rolandic areas in patients with refractory epilepsy and normal MRI submitted to subdural grids'implantation. Arq Neuropsiquiatr 59: 717-721, 2001

8. Devinsky O, Romanelli P, Orbach D, Pacia S, Doyle W: Surgical treatment of multifocal epilepsy involving eloquent cortex. Epilepsia 44: 718-723, 2003

9. Engel J, Van Ness P, Rasmussen T: Outcome with respect to epileptic seizures. In: Engel J (ed), Surgical Treatment of the Epilepsies. 2nd ed. New York:Raven Press, 1993:609-621

10. Gasser T, Ganslandt O, Sandalcioglu E, Stolke D, Fahlbusch R, Nimsky C: Intraoperative functional MRI: Implementation and preliminary experience. Neuroimage 26:685-693, 2005

11. Gross DW: Diffusion tensor imaging in temporal lobe epilepsy. Epilepsia 52 Suppl 4:32-34, 2011

12. Kaibara T, Myles ST, Lee MA, Sutherland GR: Optimizing epilepsy surgery with intraoperative MR imaging. Epilepsia 43:425-429, 2002

13. Keles GE: Intracranial neuronavigation with intraoperative magnetic resonance imaging. Curr Opin Neurol17:497-500, 2004
14. Kubicki M, McCarley R, Westin CF, Park HJ, Maier S, Kikinis R, Jolesz FA, Shenton ME: A review of diffusion tensor imaging studies in schizophrenia. J Psychiatr Res 41:15-30, 2007

15. Kunimatsu A, Aoki S, Masutani Y, Abe O, Mori H, Ohtomo K: Threedimensional white matter tractography by diffusion tensor imaging in ischaemic stroke involving the corticospinal tract. Neuroradiology 45:532-535, 2003

16. Lehman R, Andermann F, Olivier A, Tandon PN, Quesney LF, Rasmussen TB: Seizures with onset in the sensorimotor face area: Clinical patterns and results of surgical treatment in 20 patients. Epilepsia 35:1117-1124, 1994

17. Liu C, Bammer R, Kim DH, Moseley ME: Self-navigated interleaved spiral (SNAILS): Application to high-resolution diffusion tensor imaging. Magn Reson Med 52:1388-1396, 2004

18. Pondal-Sordo M, Diosy D, Téllez-Zenteno JF, Girvin JP, Wiebe $\mathrm{S}$ : Epilepsy surgery involving the sensory-motor cortex. Brain 129:3307-3314, 2006

19. Miller JH, McKinstry RC, Philip JV, Mukherjee $P$, Neil JJ: Diffusion-tensor MR imaging of normal brain maturation: $A$ guide to structural development and myelination. AJR Am J Roentgenol 180:851-859, 2003

20. Mukherjee $P$, McKinstry RC: Diffusion tensor imaging and tractography of human brain development. Neuroimaging Clin N Am 16:19-43,2006

21. Nimsky C, Ganslandt O, Buchfelder M, Fahlbusch R: Intraoperative visualization for resection of gliomas: The role of functional neuronavigation and intraoperative 1.5 T MRI. Neurol Res 28:482-487, 2006

22. Nimsky C, Ganslandt O, von Keller B, Fahlbusch R: Preliminary experience in glioma surgery with intraoperative high-field MRI. Acta Neurochir Suppl 88:21-29, 2003

23. Nimsky C, Grummich P, Sorensen AG, Fahlbusch R, Ganslandt $\mathrm{O}$ : Visualization of the pyramidal tract in glioma surgery by integrating diffusion tensor imaging in functional neuronavigation. Zentralbl Neurochir 66:133-141, 2005

24. Okada T, Mikuni N, Miki Y, Kikuta K, Urayama S, Hanakawa T, Fushimi Y, Yamamoto A, Kanagaki M, Fukuyama H, Hashimoto $\mathrm{N}$, Togashi K: Corticospinal tract localization: Integration of diffusion-tensor tractography at 3-T MR imaging with intraoperative white matter stimulation mapping-preliminary results. Radiology 240:849-857, 2006

25. Otsubo H, Chitoku S, Ochi A, Jay V, Rutka JT, Smith ML, Elliott IM, Snead OC 3rd: Malignant rolandic-sylvian epilepsy in children: Diagnosis, treatment, and outcomes. Neurology 57: 590-596, 2001

26. Otte WM, van Eijsden P, Sander JW, Duncan JS, Dijkhuizen RM, Braun KP: A meta-analysis of white matter changes in temporal lobe epilepsy as studied with diffusion tensor imaging. Epilepsia 53:659-667, 2012

27. Pilcher C, Meacham WR, Holbrook TJ: Partial excision of the motor cortex in treatment of Jacksonian convulsions. Results of forty cases. Arch Surg 54:633-643, 1947 
28. Radhakrishnan A, James JS, Kesavadas C, Thomas B, Bahuleyan B, Abraham M, Radhakrishnan K: Utility of diffusion tensor imaging tractography in decision making for extratemporal resective epilepsy surgery. Epilepsy Res 97:52-63, 2011

29. Salmenpera TM, Simister RJ, Bartlett $P$, Symms MR, Boulby PA, Free SL, Barker GJ, Duncan JS: High-resolution diffusion tensor imaging of the hippocampus in temporal lobe epilepsy. Epilepsy Res 71:102-106, 2006

30. Sundgren PC, Dong Q, Gomez-Hassan D, Mukherji SK, Maly $\mathrm{P}$, Welsh R: Diffusion tensor imaging of the brain: review of clinical applications. Neuroradiology 46:339-350, 2004
31. Winston GP, Yogarajah M, Symms MR, McEvoy AW, Micallef C, Duncan JS: Diffusion tensor imaging tractography to visualize the relationship of the optic radiation to epileptogenic lesions prior to neurosurgery. Epilepsia 52:1430-1438, 2011

32. Yang WD, Chen ZJ, Yu Q, Wang ZG, Hao ZD, Li H, Zhang CZ: Applications of blood oxygenation level dependentfunctional magnetic resonance imaging, diffusion tensor imaging and intraoperative neurophysiology monitoring in secondary epileptic surgery in M1 area. Zhonghua Yi Xue Za Zhi 90:2755-2758, 2010 